\title{
動詞の長さの分布に基づいた文章の分類と和語 及び合成語の比率
}

\author{
金明 哲 ${ }^{\dagger}$
}

文章 (テキスト)の執筆者の推定問題などに対して，文章の内容や成立に関する歴史的 事実の考証とは別に，文章から著者の文体の計量的な特徵を抽出し，その統計分析に よって問題解決を試みる研究が多くの人々の注目をあつめつつある．文章に関するど のような要素に著者の特徵が現れるかについて，欧米文に関してはいくつかの研究の 例があるが，それは言語によって異なるとも考えられるため，欧米文に関する研究成 果が日本文の場合にもあてはまるかについて実証的な研究が必要である．また，各言 語はその言語における著者の特徵を表す独特な要素があることも考えられる，本論文 では，今まで明らかにされていない，日本文における動詞の長さの分布に著者の特徴 が現れることと，その結果が動詞中の漢語・和語，合成語・非合成語の使用率の影響 ではないことを著者 3 人の計 21 の文章を用いて明らかにした。計量分析の手法とし ては，同一著者の文章における動詞の長さの分布間の距離の平均値と，異なる著者の 文章における動詞の長さの分布の距離の平均值との差，および距離マトリックスを用 いて主成分分析を行うという方法を用いて数量・視覚的文章の分類を試みた。

キーワード： 文章の分類, 動詞の長さの分布, 和語・漢語, 合成語・非合成語, 相関係数, 主成 分分析

\section{Classification of Sentences by Word-length Distribution of Verbs with Proportions of Japanese Words and those of Compound Words}

\author{
JIN MING-ZHE
}

For the identification of a unknown author of a certain literature, it is significant to find the main elements of writing styles which characterize authors or distinguish them. It was previously known that the authors' writing styles are characterized in distributions fo lengths of words are categorized by parts of speech. This paper presents a quantitative analysis of the classification of sentences by word-length distribution of verbs, and the relationships between writing styles in word-length distribution of verbs and the proportions of Japanese words and Chinese words or those of compound words and non-compound words in verbs. This analysis shows that word-length distribution of verbs characterizes writing styles even where there are no differences in the proportions of Japanese words and Chinese words or those of compound words and non-compound words.

KeyWords: classification of sentences, verb-length distribution, Japanese words and Chinese words, compound words and non-compound words, correlation coefficient, principal component analysis 


\section{1 まえがき}

文章 (文献) の執筆者の推定問題 (authorship problem)，あるいは執筆順序の推定や執筆時期 の推定などの問題 (Chronology) に対して, 文章の内容や成立に関する歴史的事実の考証とは別 に, 文章から著者の文体の計量的な特徵を抽出し, その統計分析によって問題の解決を試みる研 究が多くの人々に注目をあつめつつある.

統計分析の手法を用いた文章の著者の推定や執筆の時期の推定などの研究は今世紀の初頭か ら行なわれていたが, 本格的な研究が現れたのは今世紀の中ごろである. 研究の全体像を把握す るため今世紀の主な研究を表 1 に示した.

\section{表 1 著者の推定などの研究のリスト}

\begin{tabular}{|c|c|c|c|}
\hline 分析の対象となった文章 & 用いた情報 & 用いた情報, 手法 & 研究者 \\
\hline Shakespeare, Bacon & 単語の長さ & モード & Mendenhall, T.C.(1887) \\
\hline The Imitation of Christ & 文の長さ & 平均値, 中央值など & Yule, G.U.(1939) \\
\hline The Imitation of Christ & 語彙量 & $\mathrm{K}$ 特性值 & Yule, G.U.(1944) \\
\hline Shakespeare et al. & 単語の音節数 & Shannon エントロピー & Fucks, W.(1952) \\
\hline \multirow[t]{2}{*}{ Shakespeare et al. } & 音節数の接続関係 & 分散共分散の固有值, & \\
\hline & & Shannon エントロピー & Fucks, W.(1954) \\
\hline Shakespeare et al. & 単語の長さの分布 & 平均値など & Williams, C.B.(1956) \\
\hline プラトンの第七書簡 & 文の長さ & 平均値, 中央值など & Wake, W.C(1957) \\
\hline Work of Plato & 文末の単語の夕イプ & 判別分析 & Cox, D.R. et al. (1958) \\
\hline \multicolumn{4}{|l|}{ Quintus Curtius Snodgrass } \\
\hline letter & 語の長さの分布 & $\chi^{2}$ の検定, $t$ 検定 & Brinegar, C.S.(1963) \\
\hline 新約聖書の中のパウロの書簡 & 語の使用頻度 & $\chi^{2}$ 検定 & Morton, A.Q.(1965) \\
\hline 源氏物語の宇治十帖 & 頁数, 和歌数など & $\mathrm{U}$ 検定, $\chi^{2}$ 検定 & 安本 美典 (1960) \\
\hline Federalist paper & 単語の使用頻度 & 線形判別分析, 確率比 & Mosteller, F. et al. (1963) \\
\hline 由良物語 & 単語の使用頻度 & 線形判別分析, 確率比 & 菲沢 正 (1965) \\
\hline Shakespeare and Bacon & 単語の長さの分布 & 分布の比較 & Williams, C.B.(1975) \\
\hline Shakespeare & 語彙量 & ポアソン分布 & Thisted, R. et al. (1976) \\
\hline 源氏物語 & 頁数, 和歌数等 & 因子分析 & 安本 美典 (1977) \\
\hline Shakespeare & 単語の出現頻度 & ポアソン分布, 検定 & Thisted, R. et al. (1987) \\
\hline \multirow[t]{2}{*}{ 紅楼夢 } & 虚詞の使用頻度 & 主成分, & \\
\hline & & クラスターリング など & Li, X.P.(1987, 1989) \\
\hline \multirow[t]{2}{*}{ 日蓮遺文 } & 品詞の使用率など & $t$ 検定, 主成分, & \\
\hline & & クラスターリング & 村上 征勝 他 $(1992,1994)$ \\
\hline
\end{tabular}


文章の著者の推定や文章の分類などを行なう際, 文章に関するどのような著者の特徵を表す 情報 (特徵情報) を用いるかが問題解決の鍵である. 今までの文章の著者の推定や文体の研究で は著者の特徴を表す情報としては, 単語の長さ, 単語の使用頻度, 文の長さなどがよく用いられ ている.

日本文に関して, 少し詳細に見ると, 安本は直喻, 声喻, 色彩語, 文の長さ, 会話文, 句読点, 人 格語などの項目を用いて 100 人の作家の 100 編の文章を体言型一用言型, 修飾型一非修飾型, 会 話型一文章型に分類することを試み (安本 1981, 1994), また長編度 (頁数), 和歌の使用度, 直喻 の使用度, 声喻の使用度, 心理描写の数, 文の長さ, 色彩語の使用度, 名詞の使用度, 用言の使用 度, 助詞の使用度, 助動詞の使用度, 品詞数の 12 項目の情報を用いて源氏物語の宇治十帖の著者 の推定を試みた (安本 1958). 菲沢は，「にて」，「へ」，「して」，「ど」，「ばかり」，「しも」， 「のみ」，「ころ」，「なむ」，「じ」，「ざる」，「つ」，「む」，「あるは」，「されど」，「しか れども」，「いと」，「いかに」などの単語の使用率を用いて，「由良物語」の著者の判定 (菲沢 1965，1973) を行い, 村上らは品詞の接続関係, 接尾語などを用いて日蓮遺文の真偽について計 量分析を行なっている(村上 $1985,1988,1994)$. このように, 日本文に関して, 文章の著者の推 定を試みる研究はいくつかあるが, 著者の推定などのための文章に関するどのような情報が有効 となるかに関する基礎的な研究はほとんどない状況である.

文章に関するどのような要素に著者の特徴が現れるかに関して, 外国での研究ではいくつか あるが, それは言語によって異なると考えられるため, 外国語での研究成果が日本語の場合もあ てはまるのか，もしあてはまらないとすれば日本語の文章ではどのような要素に著者の特徵が現 れるかというようなことが文体研究の重要な課題である.

筆者は日本語の文章の著者の推定あるいは著者別に文章を分類する基礎的な研究として, 文 章の中のどのような要素が著者の文体の特徵になるかについて研究を進めている. コンピュータ のハードウエアとソフトウエアの発展に伴い, コンピュータを利用することによって文章の中か ら膨大な情報が抽出できるようになった. しかし, 今度はそのような膨大な情報の中からどの情 報を用いるべきかという新しい問題が生じた. 筆者らは文章の中に使用された読点について計 量分析を行ない, 読点の前の文字に関する情報で文章を著者別に分類する方法を提案し, この方 法は文学作品だけではなく研究論文についても有効であることを実証した (金 $1993 \mathrm{a}, \mathrm{b}, 1994 \mathrm{c}$, $\mathrm{d}, \mathrm{e})$. このような日本文に適応した著者の文体の特徵情報の抽出に関する研究は始まったばか りで決して十分とはいえない。

ところで, コンピュータで著者の文体の特徵を抽出するためには計算機処理可能な文章の データベースが必要であるが，そのようなデータベースが入手できなかったため, 作成すること にした. データベース化したのは井上靖, 三島由紀夫, 中島敦の短篇小説である. 分析に用いた 情報の安定性の考察及び用いた短い文章とのバランスをとるため, 此較的長い文章はいくつかに 分割して用いた. 例えば, 井上の「恋と死と波と」は二つに, 中島の「弟子」は三つに，「李陵」 
は四つに分割して用いることにした. 表 2 に, 用いた文章と発表年などを示した.

表 2 分析に用いた文章のリスト

\begin{tabular}{|c|c|c|c|c|c|}
\hline 著者 & 文章名 & 記号 & 単語数 & 出版社 & 発表の年 \\
\hline \multirow[t]{8}{*}{ 井上靖 } & 結婚記念日 & I1 & 4749 & 角川文庫 & 1951 \\
\hline & 石庭 & $\mathrm{I} 2$ & 4796 & 同上 & 1950 \\
\hline & 死と恋と波と (前半) & I3 & 4683 & 同上 & 1950 \\
\hline & 死と恋と波と (後半) & I4 & 4386 & 同上 & 同上 \\
\hline & 帽子 & I5 & 3724 & 新潮文庫 & 1973 \\
\hline & 魔法䭪 & I6 & 3624 & 同上 & 同上 \\
\hline & 滝へ降りる道 & I7 & 3727 & 同上 & 1952 \\
\hline & 晚夏 & I8 & 4269 & 同上 & 同上 \\
\hline \multirow[t]{4}{*}{ 三島由紀夫 } & 遠乗会 & M1 & 4984 & 新潮文庫 & 1951 \\
\hline & 卵 & M2 & 4004 & 同上 & 1955 \\
\hline & 詩を書く少年 & M3 & 4502 & 同上 & 1955 \\
\hline & 海と夕焼 & M4 & 3359 & 同上 & 1955 \\
\hline \multirow[t]{9}{*}{ 中島敦 } & 山月記 & L1 & 3226 & 新潮文庫 & 1942 \\
\hline & 名人伝 & L2 & 3202 & 同上 & 1942 \\
\hline & 弟子 (前の $1 / 3$ ) & L3 & 4078 & 同上 & 1943 \\
\hline & 弟子 (中の $1 / 3$ ) & L4 & 4092 & 同上 & 同上 \\
\hline & 弟子 (後の 1/3) & L5 & 3727 & 同上 & 同上 \\
\hline & 李陵 (前の $1 / 4)$ & L6 & 4563 & 同上 & 1944 \\
\hline & 李陵 (中の $1 / 4$ ) & L7 & 4561 & 同上 & 同上 \\
\hline & 李陵 (中の $1 / 4$ ) & L8 & 4638 & 同上 & 同上 \\
\hline & 李陵 (後の 1/4) & L9 & 4458 & 同上 & 同上 \\
\hline
\end{tabular}

この 3 人を選んだのは, OCR(光学読み取り装置)で文章を入力する場合に漢字の認識率が問 題になるため, 現代文の中で漢字の使用率がわりに高い中島の文章を用いて OCR での入力テス トを行なったのがきっかけであった. 中島と同時期の作家として井上, 三島を選んだ.

データベースは分析に用いる文章を OCRで入力し, 読み取りの誤りを訂正し, 品詞コードな どを入力して作成した. 表 3に作成したデータベースの一部分を示した. 単語の認定は「広辞苑」 に従った. ただし, 広辞苑にない複合動詞については複合された全体を 1 語とした.

\section{2 単語の長さの分布に基づいた文章の分類}

文章の中の著者の特徵情報を用いて, 文章の著者を推定するためには, 用いた情報に基づい て文章を分類する際, 文章が著者別に分類できることが望まれる.

どのような単語を好んで用いるのか, どのような長さの単語を好んで用いるのかは著者の文 章の一つの特徵であると考える. 前者を用いる場合は, 著者の好みの単語が何であるかを見つけ 出すのはかなり厄介なことである. 前者にくらべ後者はわりに簡単である.

欧米では, 著者の推定などの研究には単語の長さの情報がよく用いられている.しかし, 日本 文の分析においては, 単語の長さに関する情報はあまり用いておらず, また, 単語の長さと著者 
表 3 データベースの例

(2) /父 (M) は (J) (27) /軍医 $(\mathrm{M})$ で $(\mathrm{Z}),(4) /$ 当時 $(\mathrm{M})(5) /$ 聯隊 $(\mathrm{M})$ の ( J )

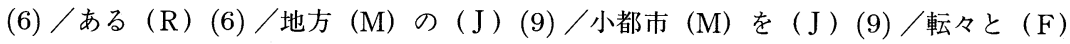

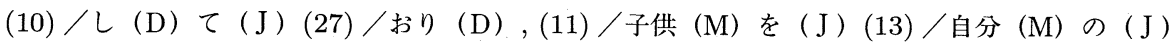

(14) /手許 (M) に（J) (27) /置く（D）と（J)，(16) /何回 (M) も (J)

(17) /転校させ (D) なけれ (Z) ば $(\mathrm{J})(23) /$ な $(\mathrm{D})$ なかっ $(\mathrm{Z})$ た $(\mathrm{Z})$ ので $(\mathrm{J})$ ，

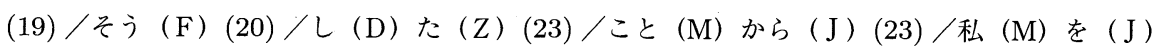

(23) /郷里 $(\mathrm{M})$ に ( J ) (24) /置く (D) $(25) /$ 気 (M)に（J) (26)/なっ (D) た (Z)

(27) /もの (M) らしかっ $(Z)$ た $(Z)$.

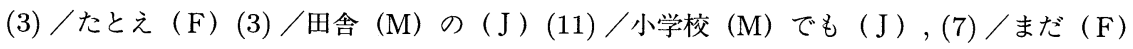

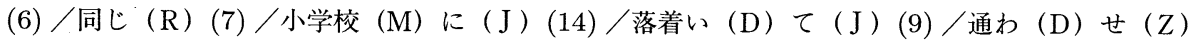

た (Z) (11)/方 (M)が (J) (11)/教育上 (M) (11)/いい (K)と (J) (13)/考え (D)

た $(Z)$ の $(\mathrm{J})$ で $(Z)(14) /$ ある (D).

記号/は文節の境界線で, (数字) は (数字)の直後の文節が係る文節の番号で, (ローマ字) は品詞コードである.

の関係に関する基礎的な研究はない.その主な原因としては,

（1）日本文は「分ち書き」されていないため単語の認定が難しいこと，

（2）日本語の機械処理技術が遅れたこと

などがあげられる (村上 $1989 \mathrm{a}, \mathrm{b})$. これらの問題は計算機科学の発展により次第に解決されて きている.今日では, コンピュータは日本語を自由に処理できるようになってきているし, 近い 将来かなり精度の良い日本文の単語分割システムも開発されると予測される (中野 1991).

筆者は実際に書かれた文字を単位とした単語の長さと著者との関係を明らかにするため, 単 語の長さの分布に著者の特徴が現れるかどうかについて計量分析を行なってきた. 分析はすべ ての単語を用いた場合と単語を名詞, 動詞, 形容詞, 形容動詞, 助詞, 助動詞, 副詞に分けた場合 の品詞別の単語の長さの分布について行なった. その結果, 日本語の単語の長さの分布を用いて 著者別に文章を分類する際, 単語を品詞別に分けていない場合には, 著者の特徴が出にくい単語 や文章の内容に依存性が高い単語などが含まれてしまうため, 分類はうまくいかないが, 単語を 品詞別に分けることによって分類の精度をあげることが可能であり, 特に動詞の単語の長さの分 布に著者の特徵が出やすいと言うことが分かった (金 $1994 \mathrm{a}, \mathrm{b})$.

本文では, 動詞の長さの分布に基づいた文章の分類及び動詞の単語の長さの分布に現れる著 者の特徵と動詞の中の和語・漢語 (漢語と和語が合成された動詞を指す. 例えば, 勉強する. 叙 述の便利のため漢語と呼ぶことにする.)、合成語・非合成語の比率との関係についての計量分析 
について述べる．まず，動詞の長さの分布を用いた文章の分類について述べておく．

表 4 に, 表 2 の 21 編の文章における実際に書かれた文字を単位とした 1 文字から 5 文字まで の長さ別の動詞の使用頻度を示した。

\section{表 4 長さ別の動詞の使用頻度}

\begin{tabular}{ccrrrrr}
\hline 著者名 & 文章の記号 & 1 & 2 & 3 & 4 & 5 \\
\hline 井上 & $\mathrm{I} 1$ & 114 & 515 & 88 & 77 & 29 \\
& $\mathrm{I} 2$ & 138 & 518 & 94 & 60 & 12 \\
& $\mathrm{I} 3$ & 117 & 492 & 119 & 73 & 17 \\
& $\mathrm{I} 4$ & 119 & 476 & 95 & 54 & 17 \\
& $\mathrm{I} 5$ & 101 & 398 & 89 & 52 & 7 \\
& $\mathrm{I} 6$ & 114 & 438 & 77 & 45 & 7 \\
三島 & $\mathrm{I} 7$ & 98 & 408 & 77 & 70 & 12 \\
& $\mathrm{I} 8$ & 110 & 429 & 87 & 85 & 17 \\
& $\mathrm{M} 1$ & 74 & 509 & 171 & 77 & 24 \\
& $\mathrm{M} 2$ & 111 & 353 & 120 & 87 & 21 \\
& $\mathrm{M} 3$ & 100 & 419 & 136 & 63 & 12 \\
& $\mathrm{M} 4$ & 68 & 379 & 92 & 58 & 8 \\
& $\mathrm{~N} 1$ & 57 & 357 & 73 & 36 & 8 \\
& $\mathrm{~N} 2$ & 60 & 340 & 104 & 43 & 7 \\
& $\mathrm{~N} 3$ & 87 & 474 & 77 & 37 & 5 \\
& $\mathrm{~N} 4$ & 73 & 480 & 86 & 42 & 11 \\
& $\mathrm{~N} 5$ & 69 & 448 & 80 & 35 & 3 \\
& $\mathrm{~N} 6$ & 74 & 503 & 124 & 51 & 17 \\
& $\mathrm{~N} 7$ & 101 & 491 & 112 & 39 & 16 \\
& $\mathrm{~N} 8$ & 90 & 490 & 116 & 55 & 13 \\
& $\mathrm{~N} 9$ & 98 & 499 & 98 & 39 & 7 \\
\hline & & & & & &
\end{tabular}

いま, 文章 $i$ の長さ $j$ の単語の使用頻度を $x_{i j}$ と表すと, $I$ 編の文章における長さ $J$ までの単語 の使用頻度と使用率のマトリックスはそれぞれ

$$
\begin{gathered}
X_{I \times J}=\left[x_{i j}\right] \\
P_{I \times J}=\left[p_{i j}\right] \\
p_{i j}=\frac{x_{i j}}{\sum_{v=1}^{J} x_{i v}}, \quad \sum_{j=1}^{J} p_{i j}=1
\end{gathered}
$$

で表示できる.

本文では, $P_{I \times J}$ の一行を一つの分布とみなし, 分布の間の距離を用いて分析を行なった. 叙 述の便利のため, 分布の間の距離を文章の間の距離と呼ぶことにする.

さて, 文章 $i$ の単語の長さの分布と文章 $l$ 単語の長さの分布の間の距離 $d_{i l}$ を次のように定 義する. 


$$
d_{i l}=\frac{1}{2} \sum_{j=1}^{J}\left(p_{i j} \log \frac{2 p_{i j}}{p_{i j}+p_{l j}}+p_{l j} \log \frac{2 p_{l j}}{p_{i j}+p_{l j}}\right)
$$

ただし

$$
\begin{array}{lll}
p_{i j}=0 & \text { なら } & p_{i j} \log \frac{2 p_{i j}}{p_{i j}+p_{l j}}=0 \\
p_{l j}=0 & \text { なら } & p_{l j} \log \frac{2 p_{l j}}{p_{i j}+p_{l j}}=0
\end{array}
$$

とする.

また上式で求められた分布の間の距離のマトリクスを

$$
D_{I \times I}=\left[\begin{array}{cc}
0 & d_{j i} \\
d_{i j} & 0
\end{array}\right]
$$

で表記する.

著者別に文章を分類する観点からは, 同一の著者 (今後は群内と呼ぶ) の任意の二つの分布の 間の距離が, 異なる著者間 (今後は群間と呼ぶ)の任意の二つの分布の間の距離より小さいこと が望まれる.しかし, 本研究ではこのような望ましい結果は得られなかった. 分類を行なう際, 文 章が著者別に分類されたとしても,グループの間の距離が十分大きくない場合は, 同一の著者の 文章の間の距離が, 異なる著者の文章の間の距離より大きい可能性も十分あり得る. そこで, 群 内の距離の平均值と群間の距離の平均值を用いて分析を進めることにする. 群内の距離の平均 值が群間の距離の平均值より小さいと, 用いた分布には著者の特徴があり, 群内の距離が群間の 距離より小さければ小さいほど著者の特徵が明確である (分類がよい) と考えられる.

著者 $k$ の $k_{n}$ 編の文章における任意の二つの分布の間の距離の平均 (今後は群内の距離と呼ぶ) を

$$
\overline{d(k)}=\frac{2 \sum_{k_{i}=k_{1}}^{k_{n}-1} \sum_{k_{j}=k_{i}+1}^{k_{n}} d_{k_{i} k_{j}}}{\left(k_{n}-1\right) k_{n}} \times 100
$$

著者 $k$ と著者 $h$ の, それぞれの $k_{n}, h_{m}$ 編の文章における任意の二つの分布の間の距離の平均 (今 後は群間の距離と呼ぶ)を

$$
\overline{d(k, h)}=\frac{\sum_{k_{i}=k_{1}}^{k_{n}} \sum_{h_{j}=h_{1}}^{h_{m}} d_{k_{i} h_{j}}}{k_{n} h_{m}} \times 100
$$

で求めた.

表 $5 に 3$ 人の 21 編の文章について, 動詞の長さの分布を用いた場合の群内, 群間の距離を示 した. 3 人の群内の距離はいずれの群間の距離より小さいため, 動詞の長さの分布には著者の特 徵があると判断する.

井上, 中島の群内の距離が三島の群内の距離に比べてかなり小さいが，これは長い文章をい くつかに分割して用いた影響ではないかと考えられる.このことを明かにするため, 長い文章を 
表 5 動詞における距離

\begin{tabular}{cccccc}
\hline 著者名 & 群内 & $\begin{array}{c}\text { 群 } \\
\text { 井上 }\end{array}$ & 三島 & $\begin{array}{c}\text { 間 } \\
\text { 中島 }\end{array}$ & 最小の群間 \\
\hline 并上 & 0.2317 & & 0.7101 & 0.5612 & 0.5612 \\
三島 & 0.5342 & 0.7101 & & 0.8513 & 0.7101 \\
中島 & 0.2630 & 0.5612 & 0.8513 & & 0.5612 \\
\hline
\end{tabular}

分割しなかった場合の各著者の群内の距離の平均值を求めてみた. 井上, 中島の群内の距離の平 均值はそれぞれ 0.2394, 0.2389 で, 長い文章を分割して用いた場合と比べて大きな差が見られな い. したがって, 井上, 中島の群内の距離が三島の群内の距離よりかなり小さいのは長い文章を 分割して用いた影響ではないと判断する. 三島の群内の距離が大きい原因としては

(1) 三島の文章における動詞の使用法の分散が大きい.

(2) 分析に用いた単語の長さの分布が十分安定していない.

などが考えられる.

長い文章をいくつかに分割した場合, 必ずしも同一の小説の文章の間の距離が, 同一の著者 の異なる小説の間の距離より小さいという結果は得られなかった.この結果については, 以下の ような原因が考えられる。

（1）動詞の単語の長さの分布は文章の内容に関して, 依存性が低い.

（2）文章における動詞の単語の長さの分布が十分安定していない.

残念ながらこの原因については用いたデータベースでは実証することが困難であるため, 今後の 研究課題にせざる得ない.

動詞の単語の長さの分布を用いた場合の分類の結果を視覚化してみる. 分類を視覚化するク ラス夕分析の方法は, いくつかの方法があるが，ここでは主成分分析を用いた. 分類を行なう際 の主成分分析としては，二つの方法が考えられる。一つは, 分類に用いるデータ

$$
\begin{gathered}
X_{I \times J}=\left[x_{i j}\right] \\
P_{I \times J}=\left[p_{i j}\right] \\
p_{i j}=\frac{x_{i j}}{\sum_{j=1}^{J} x_{i j}}, \quad \sum_{j=1}^{J} p_{i j}=1
\end{gathered}
$$

を用いて主成分分析を行なう方法で，もう一つは，上記のデータから個体間の距離 (あるいは類 似度)を求め, 距離 (あるいは類似度)のデー夕を用いて主成分分析を行なう方法である. 本研究 では後者を用いた. 主成分分析は, 求められた距離のマトリックス

$$
D_{I \times I}=\left[\begin{array}{cc}
0 & d_{j i} \\
d_{i j} & 0
\end{array}\right]
$$


を以下のように標準化し，

$$
\begin{gathered}
\widehat{d}_{i j}=\frac{d_{i j}}{\sum_{v=1}^{I} d_{i v}}, \\
\widehat{D}_{I \times I}=\left[\widehat{d}_{i j}\right],
\end{gathered}
$$

$\widehat{D}_{I \times I}$ の分散共分散の行列を用いて行なった.

動詞の単語の長さの分布を用いて求められた $\widehat{D}_{I \times I}$ の分散共分散行列の主成分分析では, 第 1 主成分, 第 2 主成分, 第 3 主成分の寄与率はそれぞれ $57.04 \%, 34.04 \%, 3.94 \%$, 第 2 主成分ま での累積寄与率は $91.08 \%$ であった. 図 1 に第 2 主成分までの主成分得点のプロットをに示した. 横軸は第 1 主成分で, 縦軸は第 2 主成分である. 主成分分析の結果から動詞の単語の長さの分布 を用いた場合, 著者別に文章が分類できるといえよう. 見やすくするため, 文章を著者別に滑ら かの曲線 (境界線) で囲んだもちろん，このような境界線はどの文章がどの著者のものである かの情報を用いて引いている.このような方法を用いて著者不明の文章の著者の判別などを行 なう場合は，まずトレーニングーデータを用いて境界線を引き, 著者不明の文章がどのグループ に属するかの判別 (判定)を行なうべきである.

\section{3 動詞における和語・漢語, 合成語・非合成語の比率}

前節では, 動詞の単語の長さの分布を用いた場合の文章の分類について述べた. 動詞の長さ の分布に著者の特徵が現れる現象の原因の一つとしては和語・漢語, 合成語・非合成語の比率が 考えられる.もし, 動詞の長さに著者の特徵が現れるという結果が, 和語・漢語, 合成語・非合成 語の比率の影響によるものであるとすると, 和語・漢語, 合成語・非合成語の比率に差がない著 者に対しては動詞の長さの分布は著者の特徵情報になれない.したがって, 動詞の単語の長さの 分布に著者の特徵が現れるという現象と和語・漢語, 合成語・非合成語の比率との関係について 明かにする必要がある.

\section{1 和語・漢語の比率}

本節では動詞は, 和語と漢語 (和語と漢語より合成された動詞) より構成されたと見なし, 動 詞の単語の長さの分布に現れる著者の特徵と和語・漢語の比率との関係について計量分析を行 なう. 和語の比率は漢語の比率より高いため, 和語の比率について分析を行なうことにする. 表 6 に 3 人作家の 21 編の文章における動詞の中の和語の比率 (動詞の中の和語の数/動詞の総 単語数) を示した. 長さ $1,4,5$ の動詞では, 和語の比率はほぼ同じで, 1 である. 長さ 2,3 の動 詞には漢語が多少含まれている. 和語の比率に著者の特徴が現れるかどうかを調べてみる. 好都 合なことに動詞の中の和語の比率に著者の特徴がありそうなのは長さ 2,3 の動詞だけであるた め, 動詞の長さ 2,3 における和語の比率を図 2 にプロットした. 横軸は長さ 2 の和語の比率で, 


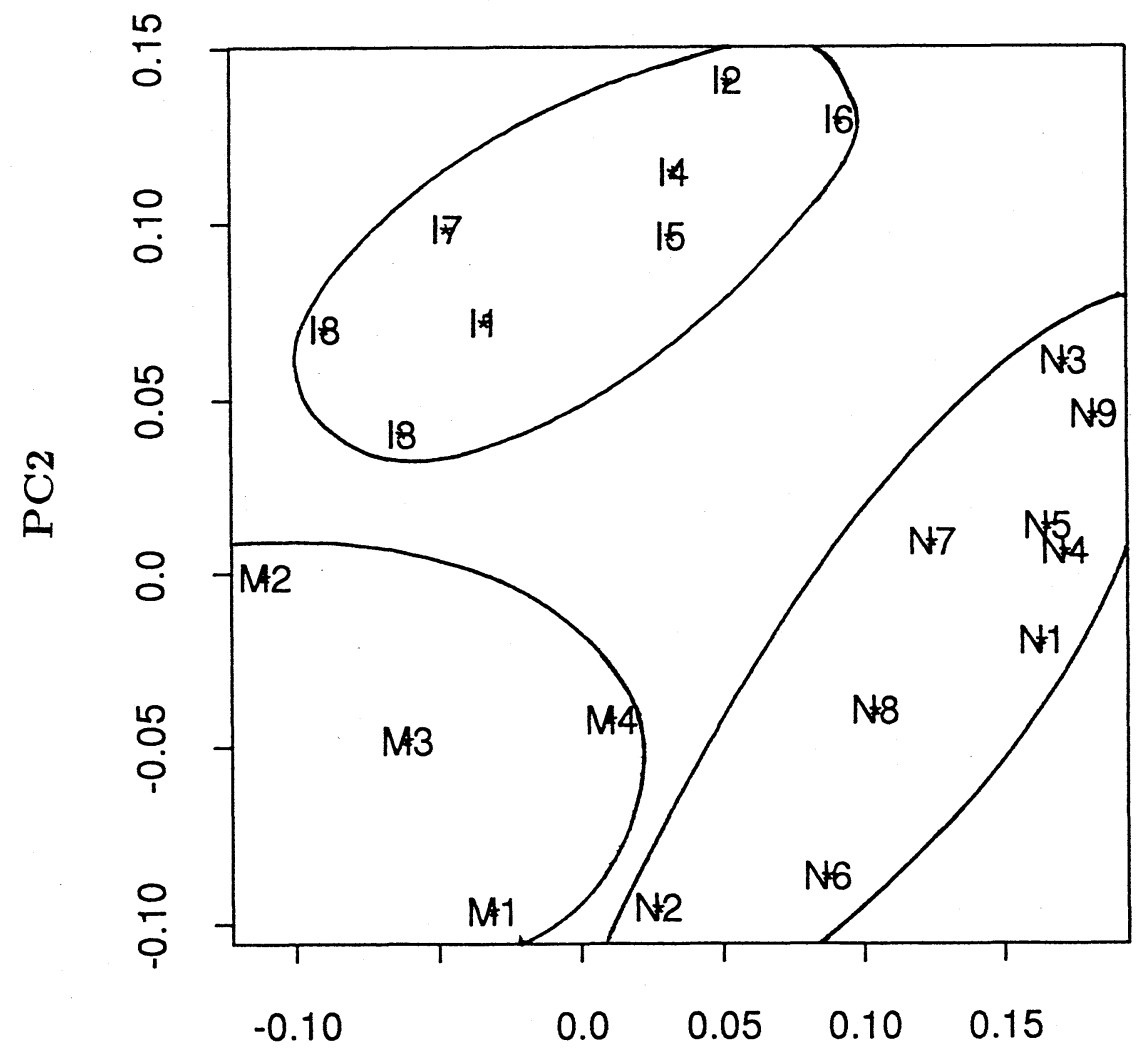

\section{PC1}

図 1 動詞の長さの分布に基づいた $\widehat{D}_{21 \times 21}$ の主成分得点のプロット

縦軸は長さ 3 の和語の比率である. 図 2 でわかるように中島は単独に一つのクループを作ってい るが, 井上と三島は著者別にクループを作っていない.つまり, 動詞の中の和語の比率には著者 の特著が現れているが, 文章を著者別に分類できるほどではない.

漢語を含んだ場合の長さの分布と漢語を除いた場合の長さの分布との関係を調べるため, 漢

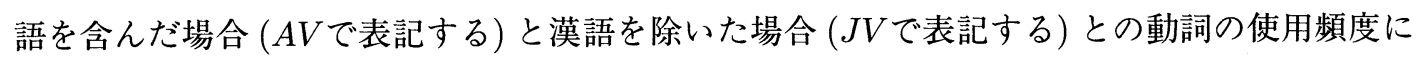
ついて相関係数を求めてみた. 相関係数が最も小さいのは $0.9843 て ゙, C O R(A V, J V)$ の対角要 素の平均は 0.9940 である. $C O R(A V, J V)$ から漢語を含んだ場合と漢語を除いた場合の動詞の 長さの分布は強い相関を持っていることが分かる. 
表 6 動詞の中の和語の比率

\begin{tabular}{cccccc}
\hline & 1 & 2 & 3 & 4 & 5 \\
\hline I1 & 1 & 0.9825 & 0.9667 & 1.0000 & 0.9600 \\
I2 & 1 & 0.9750 & 1.0000 & 1.0000 & 1.0000 \\
I3 & 1 & 0.9939 & 0.9919 & 1.0000 & 1.0000 \\
I & 1 & 0.9937 & 0.9677 & 1.0000 & 1.0000 \\
I5 & 1 & 0.9824 & 0.9778 & 1.0000 & 1.0000 \\
I6 & 1 & 0.9932 & 0.9740 & 1.0000 & 1.0000 \\
I7 & 1 & 0.9902 & 0.9750 & 0.9851 & 1.0000 \\
I8 & 1 & 0.9860 & 0.9886 & 1.0000 & 1.0000 \\
M1 & 1 & 0.9666 & 0.9765 & 1.0000 & 1.0000 \\
M2 & 1 & 0.9914 & 0.9748 & 1.0000 & 1.0000 \\
M3 & 1 & 0.9691 & 0.9209 & 1.0000 & 1.0000 \\
M4 & 1 & 0.9841 & 0.9892 & 1.0000 & 1.0000 \\
N1 & 1 & 0.9469 & 0.8472 & 1.0000 & 1.0000 \\
N2 & 1 & 0.9676 & 0.9429 & 1.0000 & 1.0000 \\
N3 & 1 & 0.9346 & 0.8816 & 0.9730 & 1.0000 \\
N4 & 1 & 0.9439 & 0.8721 & 1.0000 & 1.0000 \\
N5 & 1 & 0.9509 & 0.9620 & 1.0000 & 1.0000 \\
N6 & 1 & 0.9382 & 0.9302 & 1.0000 & 1.0000 \\
N7 & 1 & 0.9532 & 0.8654 & 1.0000 & 1.0000 \\
N8 & 1 & 0.9470 & 0.9130 & 1.0000 & 1.0000 \\
N9 & 1 & 0.9579 & 0.9200 & 1.0000 & 1.0000 \\
\hline
\end{tabular}

$C O R(A V, J V)=\left[\begin{array}{ccccc}1 & & & & \mathrm{r}_{\mathrm{ij}} \\ & 0.9864 & & & \\ & & 0.9843 & & \\ & & & 0.9998 & \\ \mathrm{r}_{\mathrm{ji}} & & & & 0.9995\end{array}\right]$

漢語を含んだ動詞の長さの分布を用いた場合の分類と漢語を除いた動詞の長さの分布を用い た場合の分類の結果を比較してみる.

第 2 章と同様な方法で, 漢語を除いた動詞の長さの分布の間の距離を用いて求めた $\widehat{D}_{21 \times 21}$ に ついて主成分分析を行なった. 第 1, 2 主成分得点の寄与率はそれぞれ $59.24 \%, 30.96 \%$, 第 2

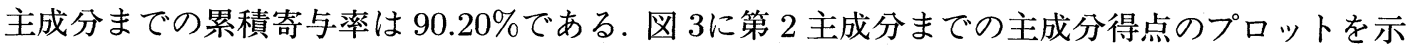
した. 主成分得点のプロットから漢語を含んだ動詞の長さの分布を用いた場合と漢語を除いた 動詞の長さの分布を用いた場合とには大きな差がないことがわかる (図 1を参照). 以上の分析結 果から, 動詞の長さの分布に現れる著者の特徵は漢語・和語の使用率の影響ではないことが分 かった. 


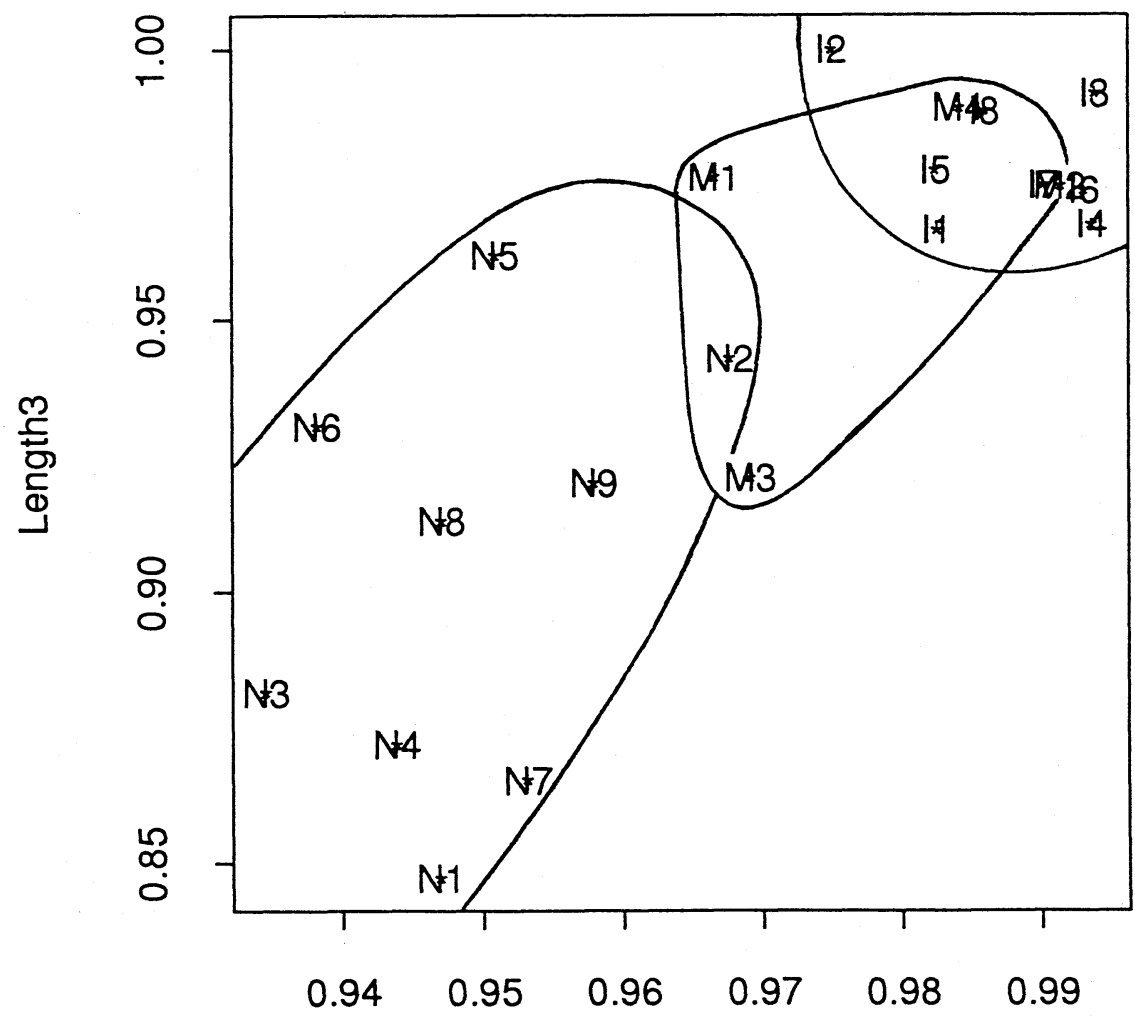

\section{Length2}

図 2 長さ 2,3 の動詞の中の和語の比率のプロット

\section{2 合成語・非合成語の比率}

本節では動詞は合成語と非合成語により構成されていると見なし, 合成語・非合成語の比率 が動詞の長さの分布に現れる著者の特徴に与える影響について分析を行なう. 非合成語の比率 は合成語の比率より高いため, 表 7 に, 動詞の中の非合成語の比率 (動詞の中の非合成語の数 / 動詞の単語総数) を示した. 表 7 から分かるように, 長さ 1,2 の動詞には合成語がない. また長 さ5における非合成語の比率は安定していないことが目立つ.これは各文章における長さ 5 の 動詞が少なかったためであると考える (情報が不安定する). 表 7のデー夕を見る限り, 著者の特 徵が現れそうなのは長さ 3 と長さ 4 の非合成語の比率である. 非合成語の比率に著者の特徴が 現れるかどうかを知るため, 長さ 3 と長さ 4 の非合成語の比率を図 4 にプロットした. 横軸は長 さ 3 の非合成語の比率で, 縦軸は長さ 4 の非合成語の比率である. 図 4 では 21 作品が著者別に グループを作っていないことから，非合成語の此率には著者の特徴が見られないと判断する. 


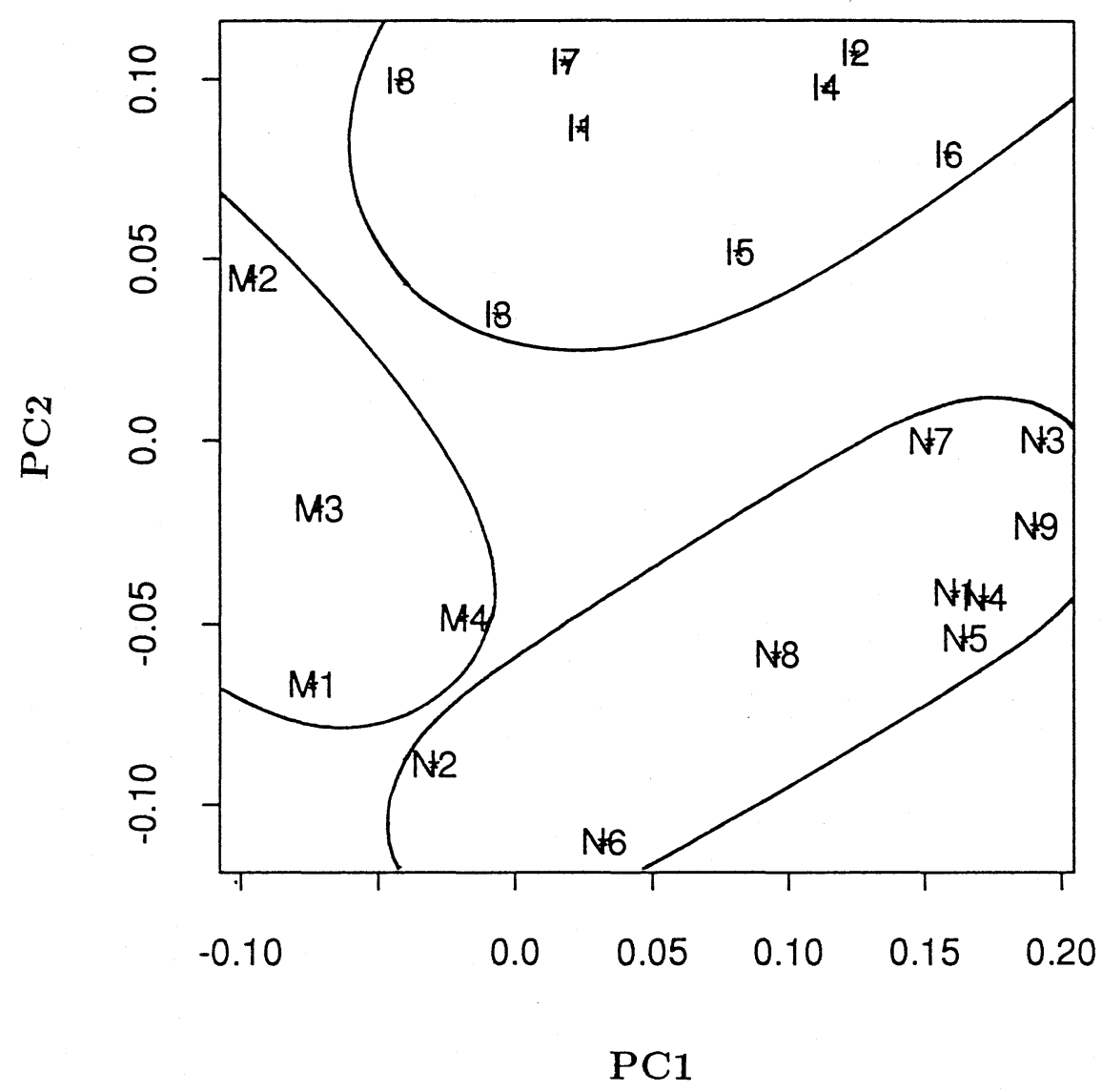

図 3 和語の動詞の長さの分布に基づいた $\widehat{D}_{21 \times 21}$ の主成分得点のプロット 
表 7 動詞の中の非合成語の比率

\begin{tabular}{cccccc}
\hline & 1 & 2 & 3 & 4 & 5 \\
\hline I1 & 1 & 1.000 & 0.7889 & 0.8571 & 0.9200 \\
I2 & 1 & 1.000 & 0.6264 & 0.8167 & 0.5455 \\
I3 & 1 & 1.000 & 0.8211 & 0.7286 & 0.8333 \\
I4 & 1 & 1.000 & 0.8602 & 0.8909 & 0.8667 \\
I5 & 1 & 1.000 & 0.6444 & 0.8235 & 0.6000 \\
I6 & 1 & 1.000 & 0.7922 & 0.9111 & 1.0000 \\
I7 & 1 & 1.000 & 0.8875 & 0.7761 & 0.8333 \\
I8 & 1 & 1.000 & 0.7273 & 0.8765 & 1.0000 \\
M1 & 1 & 1.000 & 0.7765 & 0.8571 & 0.9524 \\
M2 & 1 & 1.000 & 0.7227 & 0.9080 & 1.0000 \\
M3 & 1 & 1.000 & 0.8201 & 0.7759 & 0.9167 \\
M4 & 1 & 1.000 & 0.8387 & 0.9655 & 1.0000 \\
N1 & 1 & 1.000 & 0.8056 & 0.8333 & 1.0000 \\
N2 & 1 & 1.000 & 0.9143 & 0.8810 & 1.0000 \\
N3 & 1 & 1.000 & 0.8684 & 0.6757 & 0.6000 \\
N4 & 1 & 1.000 & 0.7442 & 0.6667 & 0.8182 \\
N5 & 1 & 1.000 & 0.6709 & 0.8000 & 1.0000 \\
N6 & 1 & 0.998 & 0.7287 & 0.7708 & 0.6429 \\
N7 & 1 & 1.000 & 0.7404 & 0.7568 & 0.1875 \\
N8 & 1 & 1.000 & 0.8348 & 0.7255 & 0.9231 \\
N9 & 1 & 1.000 & 0.7400 & 0.7368 & 0.8333 \\
\hline
\end{tabular}

合成語を含んだ動詞の単語の長さの分布 $(A V て ゙$ 表記する $)$ と, 合成語を除いた動詞の単語の 長さの分布 $(\overline{C V}$ で表記する $)$ との相関係数を求めてみた. 相関係数の中で最も小さいのは長さ が 5 の場合で, 0.8794 である. 相関係数の対角要素の平均は 0.9568 で，高い相関を持っていると 言えよう.

$$
\operatorname{COR}(A V, \overline{C V})=\left[\begin{array}{ccccc}
1 & & & & \mathrm{r}_{\mathrm{ij}} \\
& 0.9999 & & & \\
& & 0.9346 & & \\
& & & 0.9699 & \\
\mathrm{r}_{\mathrm{ji}} & & & 0.8794
\end{array}\right]
$$

合成語を含んだ場合と合成語を除いた場合との動詞の単語の長さの分布を用いた分類の結果 を比較してみた. 第 2 章で用いた方法と同じく, 非合成語における動詞の長さの分布の間の距離 を用いて求めた $\widehat{D}_{21 \times 21}$ について主成分分析を行なった. 第 1,2 主成分得点の寄与率はそれぞれ

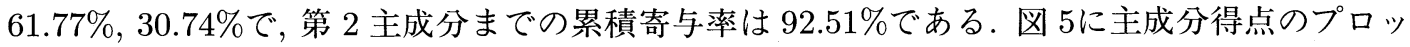
卜を示した. 主成分得点のプロットから合成語を含んだ場合と合成語を除いた場合では大きな 差がないことがわかる (図 1を参照). 長さ 5 における合成語を含んだ場合と合成語を除いた場合 の相関係数が 0.8794 であるにも関わらず分類のプロットにはあまり差が見られなかったのは， 長さ 5 の動詞の使用頻度は少なく, 分類に対する寄与も小さいためであると考える (金 1994a). 


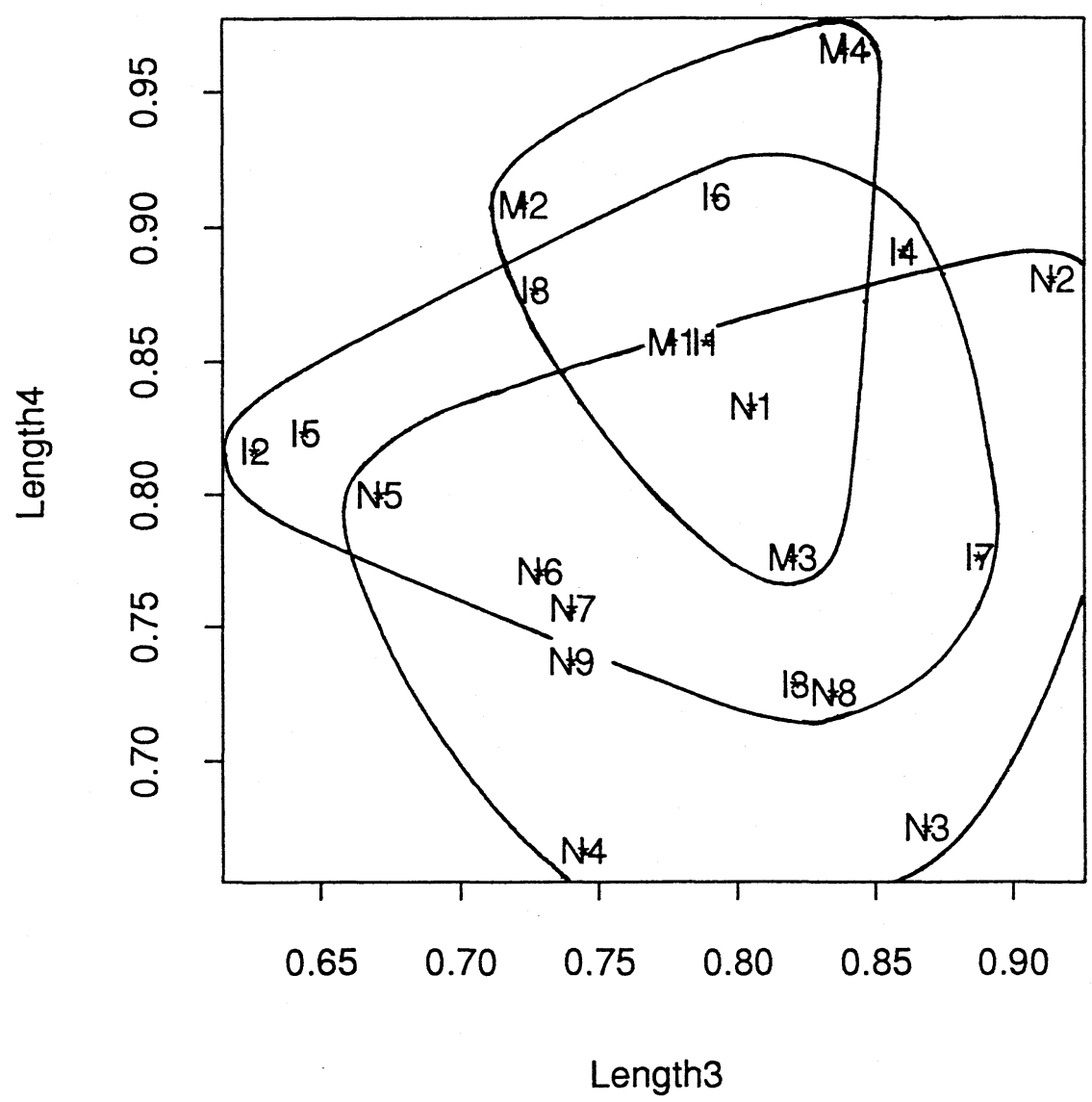

図 4 長さ 3,4 の動詞の中の非合成語の比率のプロット

以上の分析結果から, 動詞の長さの分布に現れる著者の特徴は合成語・非合成語の比率の影響で はないことがわかった.

\section{4 むすび}

本研究では, 3 人の作家の 21 編の文章における動詞の長さの分布に基づいた文章の分類及び 動詞の単語の長さの分布に現れる著者の文体の特徵と和語・漢語, 合成語・非合成語の比率との 関係について計量分析を行なった. その結果, 動詞の長さの分布は, 和語・漢語, 合成語・非合成 語の比率に著者毎の差が見られない場合でも, 著者の文体の特徵になる可能性があることを明か にした。

動詞の長さの分布を用いて分類を行なう場合の有効性の考察を行なうため, 従来よく用いら れている文の長さの分布, 品詞の使用率, 漢字・仮名の使用率, 筆者が提案した読点の前の文字 


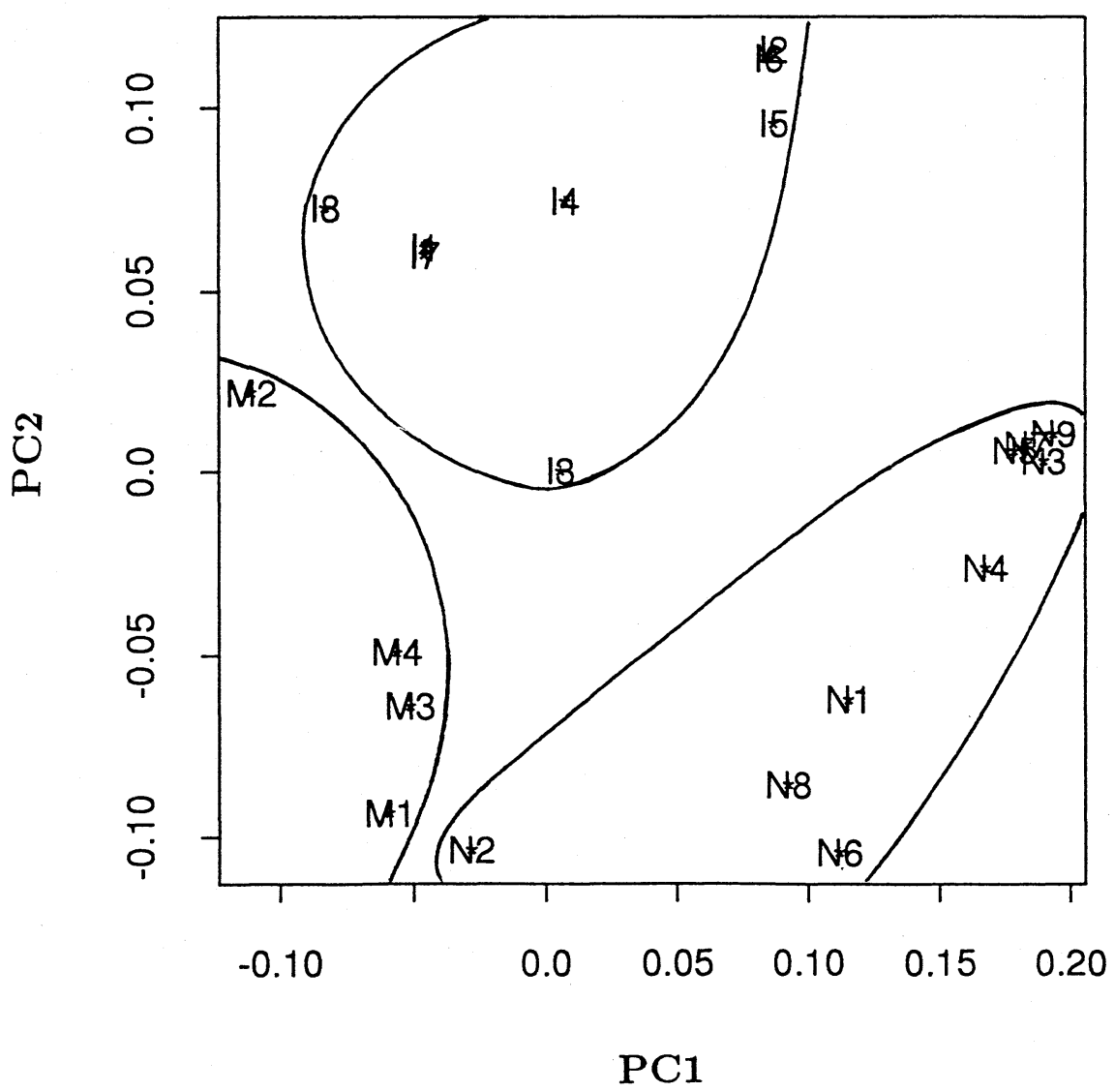

図 5 非合成語の動詞の長さの分布に基づいた $\widehat{D}_{21 \times 21}$ の主成分得点のプロット

の分布を用いた場合と比較も行なった. その結果, 最も分類がよいのは読点の前の文字の分布を 用いた場合であり，その次が動詞の長さの分布で, 従来よく用いられている文の長さの分布, 品 詞の使用率, 漢字・仮名の使用率より著者の特徵が明確に現れることが分かった (金 $1994 \mathrm{a}, \mathrm{b}, \mathrm{c}$, $\mathrm{d}, \mathrm{e})$.

動詞の単語の長さの分布だけを用いて文章を分類する場合, 分類の結果が十分に満足できる とはいえない.しかし, 著者不明の文章の著者の推定 (判別) などを行なう場合は, 無相関である 複数の文体の特徴情報を組み合わせて用いて分析を行なわなければならないため，このような文 体の特徴情報に関する研究は重要であると考える.

単語の長さを計る単位を実際に書かれた文字を単位とした場合, 単語の長さは表記文字の種 類の影響を受けることも考えられる.しかし, 本計研究に用いた動詞には平仮名やローマ字によ るものはない. 表記文字の種類が単語の長さに与える影響について考察を行なうため, 漢字・仮 
名の使用率を調べてみた. その結果, 漢字・仮名の使用率には著者の特徴が明確に現れなかった (金 1994a). 単語の長さを計る単位として音節, ローマ字を用いることも考えられるが, 今後の 課題にする.

単語の長さの分布に関する情報を抽出するためには, 品詞情報が付加されているデータベー スが必要である.このようなデータベースが入手できなっかたことと, 大量の作品のデータベー スを作成する経費がないため本研究では 3 人の 21 編文章だけを用いた分析に留まった. 今後よ り多くの作家の作品や異なるジャンルについて実証的な研究が必要であろう. また, 文章の量と 動詞の長さの分布の安定性との関係に関しても興味深い課題である.

\section{謝辞}

本研究に用いたデータベースは文部省統計数理研究所及び総合研究大学院大学の村上征勝教 授の研究費で作成しました, 本研究をご支援及び御指導下さった村上 征勝教授, 言語学及び文 体学の観点からご指導及びご助言下さった神戸学院大学の樺島 忠夫教授, 論文の仕上げにご協 力くださっ統計数理研究所の吉野諒三助教授, 有益なコメントを下さった査読者に深く感謝しま す. 本論文の最終の修正は学術振興会の特別研究員 (The JSPS Postdoctoral Fellowship) とし て国立国語研究所にいる期間中に行ないました. 特別研究員として採用して下さった学術振興 会, ご支援下さった国語研究所の江川 清, 中野 洋両部長, 米田 正人室長に心より感謝します.

\section{参考文献}

Brinegar, C.S. (1963). "Mark Twain and the Quintus Curtius Snodgrass Letter." J. Amer. Stat. Ass., 58, 85-96.

Cox, D.R. and Brandwood, L. (1958). "On a Discriminatory Problem Connected with the Words of Plato." J. R. Statist. Soc. B, 21, 195-200.

Efron, B. and Thisted, R. (1976). "Estimating the Number of Unseen Species: How Many Words did Shakespeare Know?." Biometrika, 63, 435-447.

Fucks, W. (1952). "On mathematical Analysis of Style." Biometrika, 39, 122-129.

Fucks, W. (1954). "On Nahordnung and Fernordnung in Samples of Literary Texts." Biometrika, 41, 116-132.

Herdan, G. (1958). "The Relation Between the Dictionary Distribution and the Occrrence Distribution of Word Length and Its Importance for the Study of Quantitative Linguistics." Biometrika, 45, 222-228.

伊藤瑞 ・村上正勝 (1992). 三大密法禀承の計量文献学的新研究. 大崎学報.

金明哲, 村上征勝 (Jin, M. and Murakami, M., 1993a). “Authors' Characterristic Writing Styles as Seen Through Their Use of Commas." Behaviormetrika, 20, 63-76.

金明哲, 樺島忠夫, 村上征勝 (1993b). “読点と書き手の個性.” 計量国語学, 18 (8), 382-391. 
金明哲 (1994a). “単語の長さの分布による文章の分類と分類の良さの評価.” Research memorandum, The Institute of Statistcal Mathematics, Tokyo of Japan.

金明哲 (1994b). “日本語の単語の長さの分布の情報と文章のパターン分類.”第 48 回全国大会 講演論文集 $(1)$, 情報処理学会.

金明哲 (1994c). “読点の打ち方と文章の分類.” Research memorandum, The Institute of Statistcal Mathematics, Tokyo of Japan.

金明哲 $(1994 d)$. “自然言語におけるパターンに関する計量的研究.” 博士学位論文, 総合研究大 学院大学.

金明哲 (1994e). “読点の打ち方と文章の分類.”計量国語学, 19 (7).

Li, X.P. (1987). "A New Theory of the Completion of Dreams in the Red Chamber." Fudan 学報 (社会科学版), 5, 3-16.

Li, X.P. (李賢平 1989). "Multivariate Approach in Authorship Investigation." In The Third Japan-China Symposium on Statistics, pp. 74-76.

Lindman, H.R. (1992). Analysis of Variance in Experimental Design. Springer-Verlay.

Morton, A.Q. (1965). "The Aouthorship of Greek Prose." J. R. Statist. Soc. A, 128(2), 169-233.

Mosteller, F. and Wallace, D.L. (1964). "Inference in an Authorship Problem." J. Amer. Stat. Ass., 58, 275-309.

村上征勝 (1984). “著者推定の問題に関する統計解析.” 大型計算機センターニュース $15(2)$, $47-58$, 北海道大学.

村上征勝 (1988). “文献の計量分析.” 統計数理, 11, 23-30.

村上征勝 (1989a). “著者は誰か？一計量文献学への招待－4.”数学セミナ, 2, 73-77.

村上征勝 (1989b). “著者は誰か？一計量文献学への招待－ 5.” 数学セミナ, 3, 60-63.

村上征勝 (1994). “計量的文体研究の威力と成果.”言語, 23 (2), 30-37.

中野洋 (1991). “パソコンによる語の認定処理.” 国立国語研究所研究報告集, 12, 83-130.

菲沢正 (1965). “由良物語の著者の統計的判別.”計量国語学, 33.

韮沢正 (1973). “ある統計的判別の試み.”数理科学, 117.

佐々木和枝 (1976). “文の長さの分布形””計量国語学, 78.

Thisted, R. and Efron, B. (1987). "Did Shakespeare Write a Newly-Discovered Poem?." Biometrika, 74, 445-455.

Wake, W.C. (1957). "Sentence-Length Distribution of Greek Authors." J. R. Statist. Soc. A, 20, 331-346.

Williams, C.B. (1940). "A Note on the Statistical Analysis of Sentence-Length as a Criterion of Literary style." Biometrika, 31, 356-361. 
Williams, C.B. (1956). "Studies in the History of Probability and Statistics." Biometrika, 43, $238-256$.

Williams, C.B. (1975). "Mendenhall's Studies of Word-length Distrbution in the Works of Shakespeare and Bacon." Biometrika, 62, 207-211.

安本美典 (1958). “著者の推定一源氏物語, 宇治十帖の著者についてー.”理学評論, $2(1)$.

安本美典 (1981). 因子分析法. 培風館.

安本美典 (1994). “文体を決める三つの因子.” 言語, 23 (2), 22-29.

Yule, G.U. (1939). "On Sentence-Length as a Statistical Charcteristic of Style in Prose: With Application to two Cases of Disputed Authorship." Biometrika, 30, 363-390.

Yule, G.U. (1944). The Statistical Study of Literary Vocabulary. Cambridge University press.

\section{略歴}

金 明哲： 1978 年中国吉林師範大学 (現東北師範大学) 数学系卒業. 同年中国長 春郵電学院 (大学) に就職. 1988 年 4 月来日, 宇都宮大学工学研究科, 神戸大 学工学部の外国人研究員を経て, 1991 年 10 月に総合研究大学院大学数物科 学統計科学専攻の博士後期課程に入学, 1994 年 9 月博士後期課程終了. 博士 (学術). 現在学術振興会の特別研究員 (The JSPS Postdoctoral Fellowship) として国立国語研究所で研究. 統計分析, パターン認識・分類, 自然言語に関 する研究に従事.

(1994 年 7 月 5 日受付)

(1994 年 8 月 26 日 再受付)

(1994 年 11 月 7 日 採録) 